\title{
Megacity ozone air quality under four alternative future scenarios
}

\author{
T. M. Butler ${ }^{1,2}$, Z. S. Stock ${ }^{3}$, M. R. Russo ${ }^{3,4}$, H. A. C. Denier van der Gon ${ }^{5}$, and M. G. Lawrence ${ }^{1,2}$ \\ ${ }^{1}$ Max Planck Institute for Chemistry, Mainz, Germany \\ ${ }^{2}$ Institute for Advanced Sustainability Studies, Potsdam, Germany \\ ${ }^{3}$ Centre for Atmospheric Science, Department of Chemistry, Cambridge University, UK \\ ${ }^{4}$ NCAS Climate, UK \\ ${ }^{5} \mathrm{TNO}$ - Department Climate, Air and Sustainability, Princetonlaan 6, 3584 CB Utrecht, The Netherlands
}

Correspondence to: T. M. Butler (tim.butler@iass-potsdam.de)

Received: 25 November 2011 - Published in Atmos. Chem. Phys. Discuss.: 2 January 2012

Revised: 25 April 2012 - Accepted: 4 May 2012 - Published: 16 May 2012

\begin{abstract}
The impact of the megacities of the world on global tropospheric ozone, and conversely, the extent to which megacities are influenced by emissions of ozone precursors from outside of the megacities is examined under the four alternative RCP ("Representative Concentration Pathway") emissions scenarios. Despite accounting for about $6 \%$ of present-day anthropogenic emissions of ozone precursor species, the contribution of emissions from megacities to global tropospheric ozone is calculated to be $0.84 \%$. By 2100 this contribution falls to between $0.18 \%$ and $0.62 \%$ depending on the scenario, with the lower value being for the most-polluting of the four future emissions scenarios due to stringent controls on ozone precursor emissions from highly populated areas combined with a stronger tropospheric background ozone field. The higher end of this range is from the least-polluting of the four emissions scenarios, due to lower background tropospheric ozone combined with the use of a simpler downscaling methodology in the construction of the scenario, which results in higher emissions from megacities. Although the absolute impact of megacities on global ozone is small, an important result of this study is that under all future scenarios, future air quality in megacities is expected to be less influenced by local emissions within the cities, but instead more influenced by emission sources outside of the cities, with mixing ratios of background ozone projected to play an increasing role in megacity air quality throughout the 21 st century. Assumptions made when downscaling the emissions scenarios onto the grids used in such modelling studies can have a large influence on these results; future
\end{abstract}

generations of emissions scenarios should include spatially explicit representations or urban development suitable for air quality studies using global chemical transport models.

\section{Introduction}

It is estimated that in 2008 , the urban population of the world exceeded the rural population for the first time in history, with this trend expected to continue (UNFPA, 2007). Part of this trend is a growth in the number of so-called "megacities", which are generally regarded as cities with more than about 10 million inhabitants. The movement of human populations and their associated emissions of tropospheric ozone precursor species into such geographically small regions creates "hotspots" of air pollution. Two recent European Union research projects, CityZen and MEGAPOLI have investigated the local, regional, and global implications of these pollution hotspots through their effects on the atmospheric budgets of particles, reactive nitrogen, and tropospheric ozone. In particular, tropospheric ozone is the most important form of pollution responsible for reduced crop yields, as well as having adverse effects on human health and contributing to radiative forcing of the climate system (UNEP, 2011).

The high population density in urban areas can lead to energy efficiencies which have the potential to reduce the per capita emissions of their inhabitants (Grimm et al., 2008), with potential consequences for global air quality. In the 
developed world, there have been very strong recent improvements in air pollutant emissions due to strengthening of legislation. Despite substantial increases in population and vehicle traffic, air quality in North American megacities has improved substantially over the last five decades (Parrish et al., 2011). In the USA between 1990 and 2008, total emissions of toxic pollutants (as defined by the US Clean Air Act) declined by $41 \%$ (EPA, 2010). Efforts to reduce emissions in urbanised areas of the developed world have been so successful that many studies now suggest an influence of regional and long range transport of ozone and its precursors on ozone air quality in these areas (Jacob et al., 1999; Parrish et al., 2010; Yoshitomi et al., 2011). The developing world has yet to catch up to these standards; air quality in the megacities of the developing world can be especially poor (Gurjar et al., 2008).

So far there have been few studies examining the effects of megacity emission hotspots on atmospheric chemistry at the global scale, and none examining the extent to which megacities are influenced by external pollution sources using global modelling frameworks. Mayer et al. (2000) incorporated a parameterised form of urban photochemistry into a global, two dimensional climate model with background tropospheric photochemistry in order to study the effects of urban emissions processing on global atmospheric composition. They did not specifically investigate the contribution of megacities, but rather studied the effects of urban areas in general, finding that incorporation of the effects of urban chemistry in their model reduced the amount of tropospheric ozone compared to model runs in which the effects of urban chemistry were not included.

Taking a different approach, Lawrence et al. (2007) used a global, three dimensional transport model to investigate the transport of pollutants away from megacities and other large population centres. Their model did not include any atmospheric chemistry, but rather employed tracers with fixed lifetimes of 1, 10, and 100 days. They found large differences in the regional pollution potentials of the various megacities, and that differences in the amount of vertical transport from megacities play a large role in determining the local dilution of emissions in the vicinity of megacities as well as the extent of the transport of pollutants away from megacities.

Butler and Lawrence (2009) used a global, three dimensional transport model with interactive NMHC chemistry in order to investigate the effects of emissions from megacities on global atmospheric composition. They employed an "annihilation" methodology, in which the emissions from a set of pre-identified megacity grid cells were removed from the model emission inventory, altering the total global emissions of ozone precursor species. Comparing their annihilation run with a control run using the unaltered emission inventory, Butler and Lawrence (2009) showed that the influence of megacities on tropospheric ozone was disproportionately small compared to their share of the total global emission of ozone precursors.
The present study goes beyond this previous work, and examines the sensitivity of ozone in megacity grid cells to local emissions by employing a new "redistribution" methodology, in which anthropogenic emissions from megacity grid cells in the emission inventory are not simply annihilated, but are rather reduced by a small amount, which is then redistributed throughout the remainder of the country in which the megacity is located according to the pre-existing emissions distribution present in the inventory for that country. Additionally, the present study makes use of the four updated emissions projections ("Representative Concentration pathways") for the upcoming IPCC AR5 report, and investigates the effects of the different characteristics of these emissions projections on the impact of megacities on tropospheric ozone.

In Sect. 2 the emissions datasets are described, including the methodology for redistribution of megacity emissions, and the characteristics of the emissions data which influence the representation of megacities are analysed. In Sect. 3 the modelling tools are described, including the methodology used to redistribute the megacity emissions for sensitivity studies. Results are presented in Sect. 4, and conclusions in Sect. 5.

\section{Megacity emissions}

\subsection{Global emission datasets}

The global emissions datasets used in this study are derived from the RCP (Representative Concentration Pathway, Moss et al., 2010; van Vuuren et al., 2011a) emissions, which are used as input for the CMIP5 (Coupled Model Intercomparison Project, 5) study, which includes a set of coupled chemistry-climate simulations which will (at the time of writing) be used as input for the IPCC fifth assessment report, due to be published in 2013. As described in Moss et al. (2010) and van Vuuren et al. (2011a), the RCP scenarios were selected from several available scenarios, with the goal of providing a set of scenarios which represents the range of projected 21 st century radiative forcing currently present in the scenario literature. There are four sets of RCP emissions available, which are named according to the change in radiative forcing in the year 2100 compared with preindustrial levels simulated by global climate models when forced with these emissions: RCP-2.6 (van Vuuren et al., 2011b); RCP-4.5 (Thomson et al., 2011); RCP-6.0 (Masui et al., 2011); and RCP-8.5 (Riahi et al., 2011).

The RCP-8.5 scenario, for example, leads to a global radiative forcing of $8.5 \mathrm{Wm}^{-2}$ by the year 2100 . This scenario is a so-called "baseline", or "business as usual" scenario, in which no specific measures to limit emissions of greenhouse gases are included. This scenario emphasises high population growth and low income in developing countries, with a lower rate of technology development, a continuing reliance on fossil fuels, and rapidly increasing atmospheric concentrations 
of greenhouse gases. This scenario is representative of the higher end of radiative forcing estimates present in the scenario literature (van Vuuren et al., 2011a). The RCP-2.6 scenario leads to a global radiative forcing of $2.6 \mathrm{Wm}^{-2}$ by 2100. This scenario is representative of literature on climate mitigation scenarios which aim to limit the increase in global average temperature due to human activity to $2^{\circ} \mathrm{C}$. This goal is met with efficiency improvements, capture and sequestration of carbon dioxide, and increased use of nuclear and renewable energy. The RCP-2.6 scenario includes a peak in radiative forcing of $3 \mathrm{Wm}^{-2}$ in the middle of the 21 st century, followed by a decline thereafter. For this reason it is sometimes also referred to as RCP-3PD (Peak and Decline, van Vuuren et al., 2011a). The RCP-4.5 and RCP-6.0 scenarios can be considered intermediate mitigation scenarios, leading to stabilisation of greenhouse gas concentrations at target levels by the end of the 21 st century without any overshoot (van Vuuren et al., 2011a).

The RCP scenarios were selected to provide a representative range of radiative forcings for use as input to coupled chemistry-climate models, rather than a representative range of possible emissions of air pollutants (such as NMVOC and $\mathrm{NO}_{\mathrm{x}}$ ) for use in air quality studies. Indeed, all four RCP scenarios assume stricter emission controls on air pollutants with time, leading to lower global emissions by 2100 (van Vuuren et al., 2011a), even if these lower emissions are achieved through different means: RCP-8.5 assumes that air quality legislation similar to that from developed nations will be introduced in the developing world once income rises above a certain threshold (Riahi et al., 2011); while RCP2.6 additionally includes the effects of changes in technology as well as reductions of pollutant emissions due to the co-benefits of measures to reduce greenhouse gas emissions (van Vuuren et al., 2011b).

The use of the RCP scenarios in the present study, examining the effects of megacities on atmospheric composition, necessarily dictates that the results presented here are not representative of possible futures in which controls on the emissions of air pollutants are less strict. The RCP scenarios will be the basis for a large number of publications in the next few years, including the fifth assessment report of the IPCC, so the examination of the air quality implications of these scenarios is also of interest. In the absence of scenarios specifically designed to explore alternative urbanisation pathways, the presently available literature must suffice. The present study is concerned in particular with the effects of emissions from megacities on air quality. Previous work (Butler et al., 2008) has shown that the details of the construction of gridded emissions datasets can have a large effect on the representation of emissions from megacities. The present work aims to explore these issues in the set of RCP scenarios.

Of particular interest are the different downscaling methodologies used to produce the gridded emissions datasets from the larger aggregated regions used in the gen- eration of the scenarios: RCP-2.6 and RCP-4.5 use a simple proportional downscaling technique for each country (van Vuuren et al., 2010), in which emissions at all grid points in a country are assumed to follow the same trend; RCP-8.5 includes spatially explicit changes in the distribution of population and economic activity within each country, and allocates legislated emissions reductions preferentially to grid cells in which population exposure is expected to be highest, based on observed trends of emissions reductions from cities in the USA (Riahi et al., 2011); and RCP-6.0 uses an intermediate approach, in which only the spatial changes in population and economic activity are used to downscale the emissions, with reductions in emissions being applied uniformly over each country (Masui et al., 2011).

The emission datasets, gridded at $0.5 \times 0.5$ degree resolution were obtained over the world wide web via the URL http://www.iiasa.ac.at/web-apps/tnt/RcpDb. We use gridded emissions of $\mathrm{CO}, \mathrm{NO}$, and NMVOC. For $\mathrm{CH}_{4}$, we use the "RCP Concentrations" data available from the same source.

\subsection{Identification of megacity emissions}

Our approach for identification of megacity grid cells in the gridded global emissions is similar to that of Butler et al. (2008), but has been updated to $0.5 \times 0.5$ degree resolution, made less dependent on the subjective judgement of the size of each megacity, and extended to include more megacities. In addition to the megacities included in Butler et al. (2008), this study adds the cities Santiago, Chile, St. Petersburg, Russia, and the urban agglomerations of RhineRuhr, Germany, and Po Valley, Italy.

The method for identification of the megacity grid cells is described fully in Butler et al. (2011) and is summarised here. Input data are the 2005 emissions from the RCP-8.5 data set, and the coordinates of megacities taken from the Collins World Atlas (Harpercollins Reference, 2008). A NO sion threshold similar to that used by Mayer et al. (2000) was used to identify megacity grid cells surrounding these coordinates. The threshold used was $10 \mathrm{~kg}(\mathrm{~N}) \mathrm{day}^{-1} \mathrm{~km}^{-2}$. The megacity grid cell mask so identified based on 2005 emissions was applied consistently for all future simulations of each of the RCP scenarios.

There were some exceptional cases:

- Some cities had a lower $\mathrm{NO}_{\mathrm{x}}$ emission than the threshold value and in these cases the grid cell containing the maximum $\mathrm{NO}_{\mathrm{x}}$ emissions and any surrounding grid cells within $10 \%$ of these emissions were included. These exceptions include Istanbul, Lima, Lagos and Dhaka.

- Hong Kong includes nearby Guangzhou, following Butler et al. (2008).

- Shanghai, Beijing and Johannesburg were restricted according to the geographical extent of the city (as surrounding regions also had high $\mathrm{NO}_{\mathrm{x}}$ emissions). 
Table 1. Megacities considered in this study, along with their emissions of $\mathrm{NO}\left(\mathrm{Gg} \mathrm{yr}^{-1}\right)$ from the emissions scenarios used in this study. Emissions for 2005 are from RCP-8.5, while all future years show the range of emissions from all four RCP scenarios.

\begin{tabular}{|c|c|c|c|c|c|}
\hline Country & City & 2005 & 2030 & 2050 & 2100 \\
\hline Argentina & Buenos Aires & 67 & $27-70$ & $19-85$ & $6.2-58$ \\
\hline Australia & Sydney & 97 & $30-92$ & $8.9-57$ & $8.0-13$ \\
\hline Bangladesh & Dhaka & 17 & $9.6-43$ & $11-77$ & $4.7-61$ \\
\hline \multirow[t]{2}{*}{ Brazil } & Rio de Janeiro & 26 & $17-31$ & $17-41$ & $6.4-29$ \\
\hline & Sao Paulo & 35 & $16-38$ & $23-46$ & $2.3-32$ \\
\hline Chile & Santiago & 22 & $12-22$ & $9.1-24$ & $4.7-15$ \\
\hline \multirow[t]{3}{*}{ China } & Beijing & 95 & $83-130$ & $20-140$ & $0.83-38$ \\
\hline & Shanghai & 270 & $250-330$ & $35-420$ & $4.3-110$ \\
\hline & Tianjin & 100 & 89-120 & $9.3-140$ & $0.40-40$ \\
\hline China, Hong Kong SAR & Hong Kong & 410 & $300-660$ & $80-840$ & $7.1-360$ \\
\hline Egypt & Cairo & 81 & $84-170$ & $62-180$ & $8.9-130$ \\
\hline France & Paris & 47 & $21-38$ & $1.0-27$ & $0.066-19$ \\
\hline Germany & Ruhr Valley & 130 & $33-100$ & $10-61$ & $4.4-28$ \\
\hline \multirow[t]{3}{*}{ India } & Delhi & 84 & $72-170$ & $44-230$ & $16-89$ \\
\hline & Kolkata & 88 & $76-170$ & $61-210$ & $25-99$ \\
\hline & Mumbai & 42 & $42-66$ & $45-68$ & $17-48$ \\
\hline Indonesia & Jakarta & 120 & $32-280$ & $3.1-430$ & $1.7-160$ \\
\hline Iran (Islamic Republic of) & Teheran & 98 & $77-150$ & $69-140$ & $8.0-95$ \\
\hline Italy & Po Valley & 220 & $82-150$ & $29-76$ & $7.2-33$ \\
\hline \multirow[t]{2}{*}{ Japan } & Osaka & 72 & $13-53$ & $4.1-36$ & $0.99-24$ \\
\hline & Tokyo & 140 & $27-110$ & $12-80$ & $6.3-52$ \\
\hline Mexico & Mexico City & 40 & $20-41$ & $18-39$ & $1.8-20$ \\
\hline Nigeria & Lagos & 17 & $18-35$ & $20-36$ & $15-56$ \\
\hline Pakistan & Karachi & 37 & $32-94$ & $32-130$ & $17-97$ \\
\hline Peru & Lima & 6.4 & $4.9-8.9$ & $4.4-11$ & $2.4-9.9$ \\
\hline Philippines & Manila & 23 & $6.6-42$ & $0.64-47$ & $0.21-27$ \\
\hline Republic of Korea & Seoul & 300 & $93-310$ & $53-190$ & $29-84$ \\
\hline \multirow{2}{*}{ Russian Federation } & Moscow & 240 & $82-210$ & $29-96$ & $0.10-24$ \\
\hline & St. Petersburg & 51 & $17-52$ & $6.5-18$ & $0.043-5.7$ \\
\hline South Africa & Johannesburg & 87 & 7.4-97 & $5.0-97$ & $2.3-100$ \\
\hline Thailand & Bangkok & 60 & $25-110$ & $22-150$ & $8.9-36$ \\
\hline Turkey & Istanbul & 13 & $6.2-9.5$ & $4.4-8.7$ & $2.1-5.8$ \\
\hline United Kingdom & London & 120 & $36-100$ & $2.6-65$ & $0.56-28$ \\
\hline \multirow[t]{3}{*}{ United States of America } & Chicago & 130 & $36-120$ & $20-72$ & $11-28$ \\
\hline & Los Angeles & 160 & $46-140$ & $27-92$ & $13-33$ \\
\hline & New York & 330 & $47-290$ & $14-200$ & $6.2-72$ \\
\hline
\end{tabular}

- The Po Valley and Rhine-Ruhr regions were added based on their definitions within the EU MEGAPOLI project.

- New York includes New Jersey and Philadelphia but not Boston or Washington DC, different to Butler et al. (2008).

The megacities considered in this study are listed in Table 1, along with their emissions of NO in 2005, and the range of projected emissions in 2030, 2050, and 2100 from the four RCP scenarios. In general, megacity emissions are projected to decrease in all four RCP scenarios. Despite all RCP scenarios assuming increasingly stringent air quality control legislation with time, there are some large differences between projected emissions from individual cities.
In general, the low end of the range of megacity emissions is from RCP-8.5, which specifically assumes lower emissions in highly populated regions as part of its downscaling methodology (Sect. 2.1). Figures S1-S3 of the Supplement to this article show the temporal evolution of individual megacity emissions between 1900 and 2100 of NO, CO, and NMVOC. The differences between the emissions from each RCP scenario are analysed in more detail in Sect. 2.3.

\subsection{Analysis of emissions}

The time series of the global, annual, historical anthropogenic emissions of $\mathrm{CO}_{2}, \mathrm{CO}, \mathrm{NO}$, and $\mathrm{NMVOC}$ from 1900 to 2000 , and the projected emissions to 2100 from the four RCP data sets are shown in Fig. 1. This includes land-based 

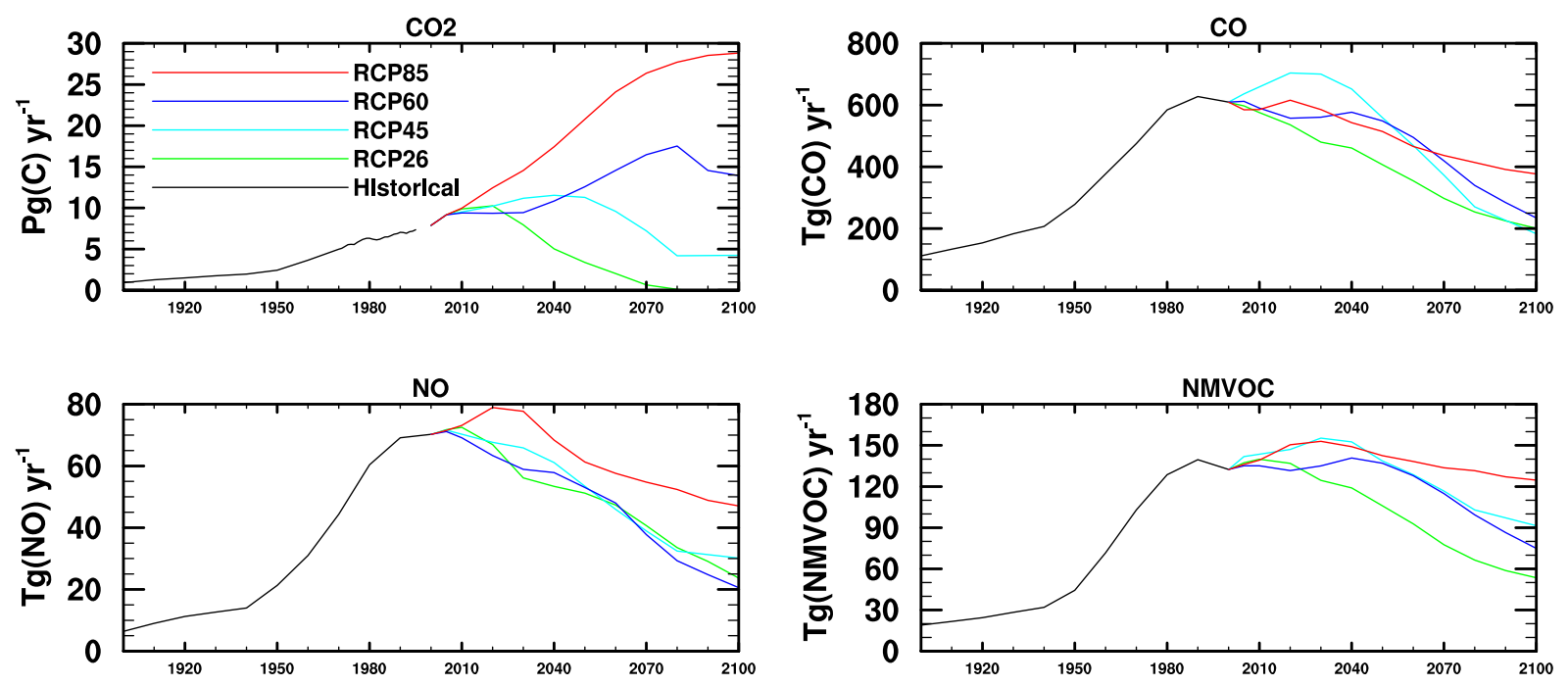

Fig. 1. $200 \mathrm{yr}$ timeseries of global anthropogenic emissions for $\mathrm{CO}_{2}, \mathrm{CO}, \mathrm{NO}$, and NMVOC.

sources as well as emissions due to shipping and aircraft. In the cases of $\mathrm{CO}, \mathrm{NO}$, and NMVOC, the historical anthropogenic emissions are taken from the gridded files described by Lamarque et al. (2010). The projected future emissions are taken from the gridded RCP files described in Sect. 2.1. Future emissions of $\mathrm{CO}_{2}$ for the four RCP projections are not available in the gridded files, so these are taken from a spreadsheet downloaded from the website given in Sect. 2.1. Historical emissions of $\mathrm{CO}_{2}$ are taken from the EDGARHYDE emission inventory (version 1.4, van Aardenne et al., 2001). Compared with emissions of $\mathrm{CO}_{2}$, the projected future emissions of $\mathrm{CO}, \mathrm{NO}$, and NMVOC show relatively less divergence between the four sets of RCP projections, consistent with the decoupling of air pollutant emissions from greenhouse gas emissions in the RCP scenarios, as mentioned in Sect. 2.1. In general, however, global emissions of these ozone precursor species are higher in RCP-8.5 than in the other scenarios, despite a smaller contribution from megacities in RCP-8.5 (Sect. 2.2).

Figure 2 shows the evolution of total global NO emissions through the 21st century broken down into shipping, landbased (megacity and non-megacity) and aircraft sources. Under all scenarios, land-based emissions of NO decrease through the 21st century. Anthropogenic NO emissions under the RCP-2.6 scenario decrease especially sharply near the end of the 21 st century due to an especially large decrease in the magnitude of aircraft and shipping emissions. Ship emissions of NO remain relatively constant throughout the $21 \mathrm{st}$ century under the RCP-8.5 scenario, and aircraft emissions even increase.

The percentage of historical and projected future anthropogenic emissions of ozone precursor species due to megacities is shown in Fig. 3. Compared with the large changes in the global total emissions (Fig. 1), the relative proportion of global ozone precursor emissions due to megacities remains relatively constant during the period 1900-2100, with a few exceptions. The large increase in the megacity percentage of total anthropogenic NO emissions (Fig. 3) under RCP-2.6 in the latter part of the 21st century is due to the coincident large decrease in the contribution of aircraft and shipping emissions under this scenario. The large decrease in the megacity percentage of all ozone precursor emissions in RCP-8.5 (Fig. 3) is due to the relatively sophisticated method of downscaling the emissions to the $0.5 \times 0.5^{\circ}$ grid, as discussed in Sect. 2.1.

The effect of the different downscaling methodologies on the distribution of emissions is shown in more geographical detail in Fig. 4, in which the land-based anthropogenic emissions of NO in the year 2100 are compared with those from the year 2000. The percentage change in emissions is calculated as $\left(\frac{E_{2100}-E_{2000}}{E_{2000}}\right) \times 100$, where $E_{2000}$ and $E_{2100}$ are the emissions in 2000 and 2100 , respectively.

The top two panels in Fig. 4 show this comparison for aggregated NO emissions from all sectors RCP-2.6 and RCP-8.5, respectively. In both cases it appears that the change in emissions from 2000 to 2100 is geographically heterogeneous; within each country there are regions in which the total NO emissions increase, and regions in which the total NO emissions decrease. This is not always due to shifts in the geographical distributions of the emissions in the individual sectors. To demonstrate this, the bottom panels of Fig. 4 show the same comparison for emissions from only the domestic sector. It is clear that for RCP-2.6, the domestic sector $\mathrm{NO}$ emissions for the year 2100 have been derived from the domestic sector NO emissions from the year 2000 by simply multiplying the year 2000 emissions by a constant factor for each country. This is the effect of the proportional downscaling algorithm use in RCP-2.6 and RCP-4.5 (Sect. 2.1). 

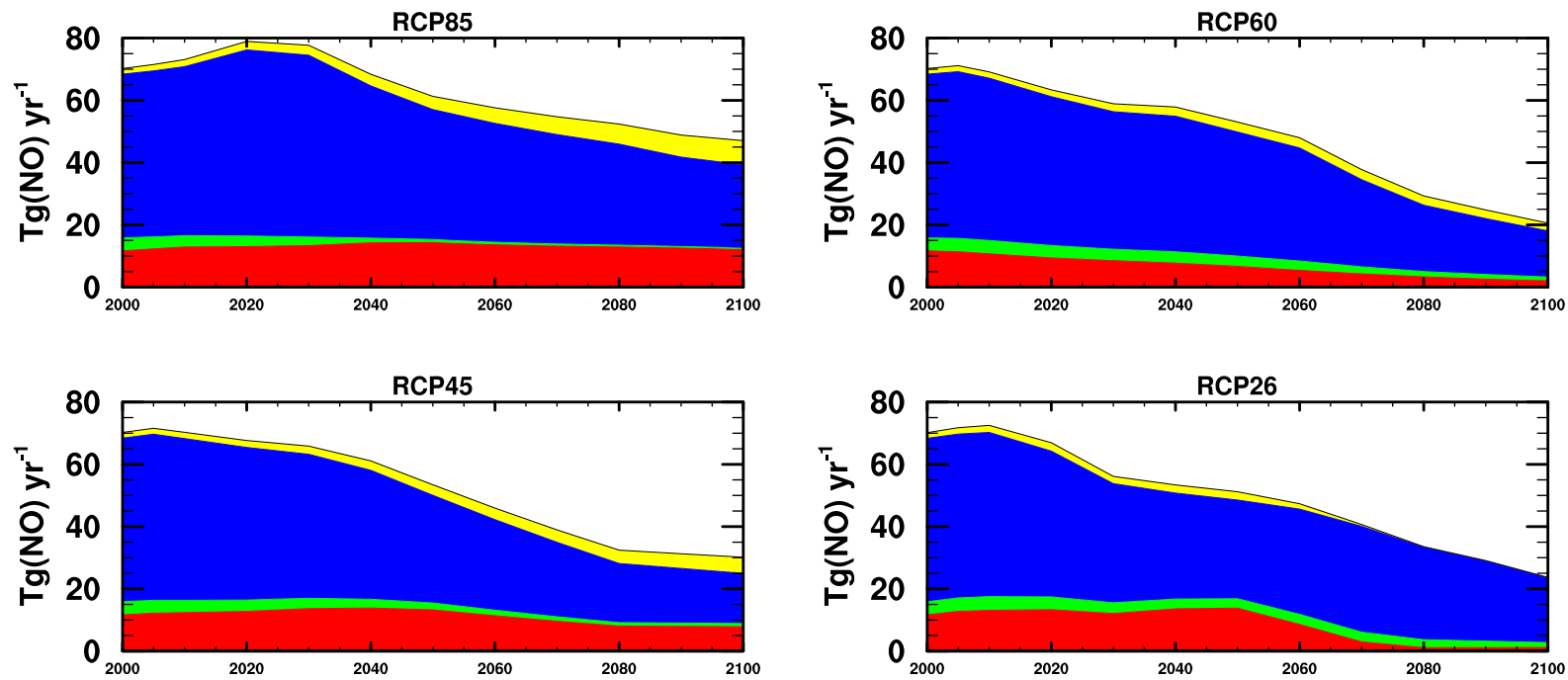

Fig. 2. Contribution of ships (red) megacities (green) other land-based sources (blue) and aircraft (yellow) to the total global anthropogenic emissions of NO.
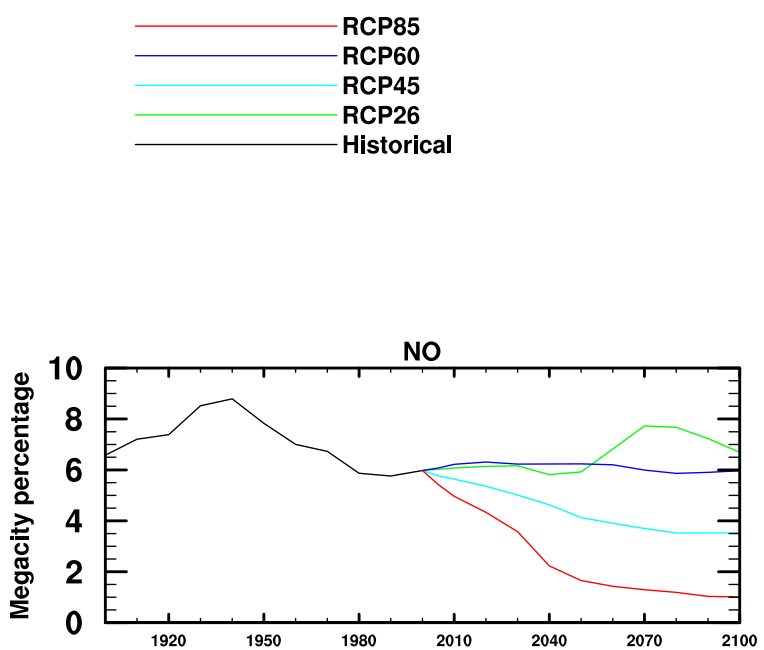

Fig. 3. Percentage of anthropogenic emissions due to megacities.

Under these scenarios underlying distributions for each emissions sector in each country do not change; the geographical structure in the changes of emissions over time under RCP2.6 and RCP-4.5 is due to the combination of constant countrywide changes in the various emission sectors. The downscaling algorithm used in RCP-6.0 is not as complex as that used in RCP-8.5 (Sect. 2.1); the absence of any assumptions about which grid cells preferentially receive the benefits of emissions control legislation do not lead to the same reductions in the percentage of emissions of ozone precursors due to megacities in RCP-6.0 as seen in RCP-8.5 (Fig. 3). The large increase in the megacity percentage of $\mathrm{CO}$ emissions (Fig. 3) under the RCP-6.0 scenario can be explained by an
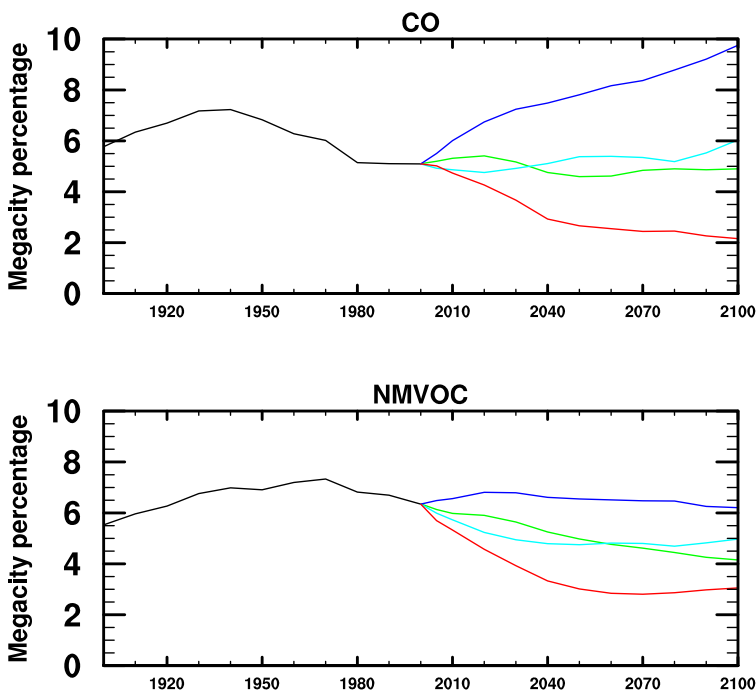

increase in the $\mathrm{CO}$ emissions from Chinese megacities under this scenario.

In order to assess the effect of the different downscaling methodologies on megacities in our simulations, we perform an additional set of model runs based on RCP-8.5, in which the country total emissions for each sector in each scenario year are proportionally downscaled similarly to the RCP-2.6 scenario. This variant on the RCP-8.5 is denoted as RCP-8.5-P. It is constructed from the original gridded RCP-8.5 scenario files by first aggregating the emissions from each sector and each country, and then redistributing them according to the per-sector and per-country geographical distribution present in year 2005 of the gridded RCP-8.5. 

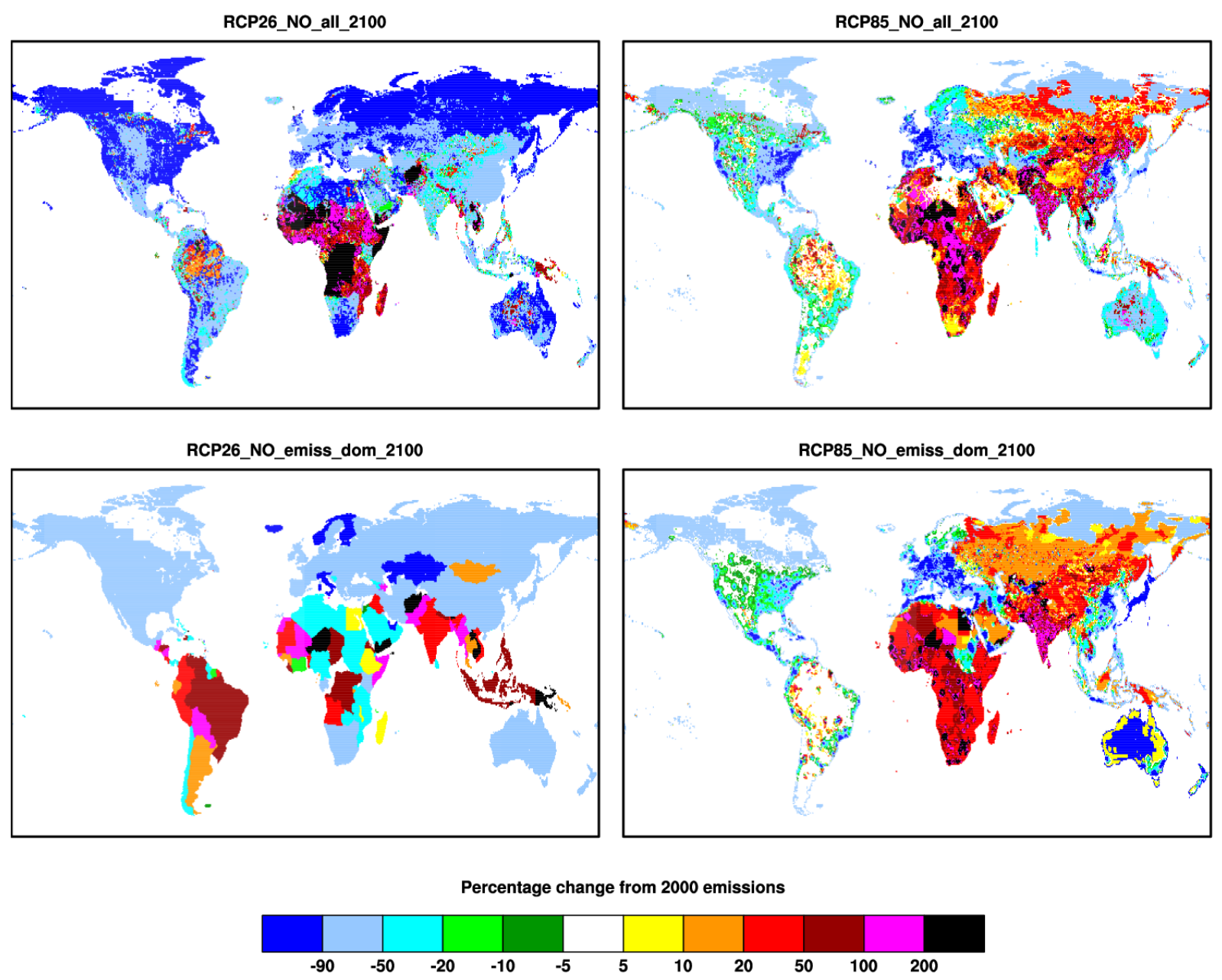

Fig. 4. Percentage change in $2100 \mathrm{NO}$ emissions relative to 2000 for RCP-2.6 (left) and RCP-8.5 (right). The top row shows total NO emissions, and the bottom row shows only emissions from the domestic sector.

\section{Modelling approach}

Simulations are carried out with the global, three dimensional chemical transport model MATCH-MPIC (Model of Atmospheric Transport and CHemistry, Max Planck Institute for Chemistry version. Lawrence et al., 1999; von Kuhlmann et al., 2003). MATCH-MPIC is run in a semi-offline mode, relying only on a limited set of input fields (surface pressure, geopotential, temperature, horizontal winds, surface latent and sensible heat fluxes, and zonal and meridional wind stresses). These fields are used to diagnose online the transport by advection, vertical diffusion and deep convection, as well as the tropospheric hydrological cycle (water vapour transport, cloud condensate formation and precipitation). Input fields are taken from the NCEP GFS (National Center for Environmental Prediction Global Forecast System). MATCH-MPIC includes background tropospheric chemical reactions as well as reactions of anthropogenic and biogenic NMVOC (Non-Methane Volatile Organic Compounds). This model has participated in several model intercomparison studies (Shindell et al., 2006; van Noije et al., 2006; Stevenson et al., 2006; Prather et al., 2003), and is used regularly for the planning and analysis of airborne field measurement campaigns (Voigt et al., 2010; Klippel et al., 2011). MATCHMPIC has been previously used to study the global impacts of megacities (Butler and Lawrence, 2009) as well as the dispersion of pollution from megacities (Lawrence et al., 2007).

Due to the computational constraints imposed by running a large number of simulation cases, a relatively coarse model resolution of T42 (approximately $2.8 \times 2.8^{\circ}$ ), with a vertical resolution of 42 levels is chosen. An advantage of using such a low resolution is that this enables a broader range of simulations to be done than would be possible with a more highly resolved model. It is expected that the use of such a coarsely resolved model with such a highly resolved gridded emissions field $\left(0.5 \times 0.5^{\circ}\right)$ will lead to biases due to the instantaneous dilution of the emissions into the model grid cells, as well as other differences in the resolution of atmospheric transport, compared with a more highly resolved model. 
In particular, the dilution of $\mathrm{NO}_{\mathrm{x}}$ emissions resulting from coarse model resolution is expected to shift the chemical regime of polluted regions away from the $\mathrm{NO}_{\mathrm{x}}$ saturated (or VOC limited) state and towards the $\mathrm{NO}_{\mathrm{x}}$ limited state (e.g. Kleinman, 1994; Sillman, 1999). These biases are likely to be especially strong in the megacity grid cells of the present study, which are defined in part according to their $\mathrm{NO}_{\mathrm{x}}$ emissions (Sect. 2.2). Wild and Prather (2006) studied these biases using a global chemical transport model run at resolutions ranging from $\mathrm{T} 21\left(5.6 \times 5.6^{\circ}\right)$ to $\mathrm{T} 106\left(1.1 \times 1.1^{\circ}\right)$. They found that the increased $\mathrm{NO}_{\mathrm{x}}$ limitation in polluted regions due to higher model resolution tended to reduce local ozone production in these regions. Comparing changes in ozone budget terms from a sequence of model runs at T42-T63T106 resolution, Wild and Prather (2006) derived values for the limit of infinite resolution $\mathrm{T} \infty$, and used these as the basis for estimating errors at lower model resolutions. They estimated that the response of regional ozone production to emissions perturbations was biased by $13 \%$ at T42 resolution, with the ozone response to increased regional precursor emissions being higher than expected from an infinitelyresolved model. Wild and Prather (2006) also noted that other model biases, such as errors in emissions, transport processes, and chemical mechanisms are more important than the effects of grid resolution for simulation of regional scale tropospheric ozone with global chemical transport models.

In the present study, 48 different model runs are performed, each with a duration of 12 months plus a spinup time of 15 weeks. Simulations of the base year, 2005, use the RCP-8.5 emissions and simulations of the years 2030, 2050 , and 2100 use the four different sets of RCP emissions (RCP-2.6, RCP-4.5, RCP-6.0, and RCP-8.5) as well as the modified version of RCP-8.5, RCP-8.5-P. In each case, for each year and each scenario, three sets of simulations are performed: a "base" set using the standard version of the emission dataset; a "masked" set using the approach of Butler and Lawrence (2009), and a "redistributed" set using the novel redistribution methodology described in Sect. 3. Mixing ratios of methane for each simulated year in each RCP scenario are fixed throughout the entire model domain at the recommended values from the RCP website (Sect. 2.1): for the 2005 runs methane is fixed at $1750 \mathrm{ppb}$; the RCP- 8.5 runs increase over the 21 st century to $3750 \mathrm{ppb}$; the RCP-2.6 runs decrease to $1250 \mathrm{ppb}$; while runs done for RCP-4.5 and RCP-6.0 initially increase methane to 1830 and $1890 \mathrm{ppb}$ by 2050 before declining to 1580 and $1650 \mathrm{ppb}$ by 2100 , respectively. All simulations are performed with input meteorology from the year 2005. Biogenic emissions of isoprene $\left(350 \mathrm{Tg}(\mathrm{C}) \mathrm{yr}^{-1}\right)$, along with soil NO emissions $\left(5.5 \mathrm{Tg}(\mathrm{N}) \mathrm{yr}^{-1}\right)$ and lightning NO emissions $\left(2.5 \mathrm{Tg}(\mathrm{N}) \mathrm{yr}^{-1}\right)$ are used for all simulations. All anthropogenic $\mathrm{NO}_{\mathrm{x}}$ emissions are emitted as NO.

\section{Redistribution methodology}

Previous work (Butler and Lawrence, 2009) employed the "annihilation" technique to study the effects of megacity emissions. Using this technique, the total global emissions of ozone precursor species are changed, allowing the calculation of the effect of the removed emissions on the global mixing ratio of tropospheric ozone. In the model grid cells close to the regions in which emissions are annihilated, unrealisticly large changes in the mixing ratios of ozone and its precursors are produced. In this study, in addition to using the simple annihilation technique, the local impact of megacities is also explored by reducing each anthropogenic emissions sector in the identified megacity grid cells by $25 \%$, and redistributing these emissions over the country to which the megacity belongs according to the geographical distribution of each emissions sector already present in the emission dataset. This redistribution approach ensures that the total global emissions of each chemical species in each emission sector remain constant, which allows the investigation of the local effects of megacities in more detail. The $25 \%$ change in megacity emissions is similar in magnitude to the $20 \%$ change in continent-scale emissions used by Fiore et al. (2009) to investigate intercontinental sourcereceptor relationships for ozone, which is large enough to provide a clear signal of the response of the system to the perturbation, while also being small enough to minimise the nonlinear effects of ozone production chemistry (e.g. Kleinman, 1994; Sillman, 1999).

\section{Results}

\subsection{Global scale}

The global, tropospheric ozone column density from the 2005 base model run is shown in Fig. 5, top panel. The distribution of tropospheric ozone in this model run largely reflects the geographical distribution of ozone precursor emissions, with higher values in the northern hemisphere, and particularly large values over strong emissions regions in Asia and North America. This is consistent with previous work (e.g. Stevenson et al., 2006). The middle and bottom panels of Fig. 5 show the percentage change in the tropospheric ozone column density from the masked model run and the percentage change in surface ozone mixing ratio from the redistributed run. The masked and redistributed runs will be discussed in more detail below.

The global, tropospheric ozone column densities from the base model runs for 2005, 2030, 2050, and 2100 from RCP-8.5, RCP-8.5-P, RCP-6.0, RCP-4.5, and RCP-2.6 are given in Table 2, along with the percentage reduction of this quantity in the corresponding "masked" run. All scenarios except for RCP-8.5 and RCP-8.5-P show decreasing tropospheric ozone column density by the year 2100 , 

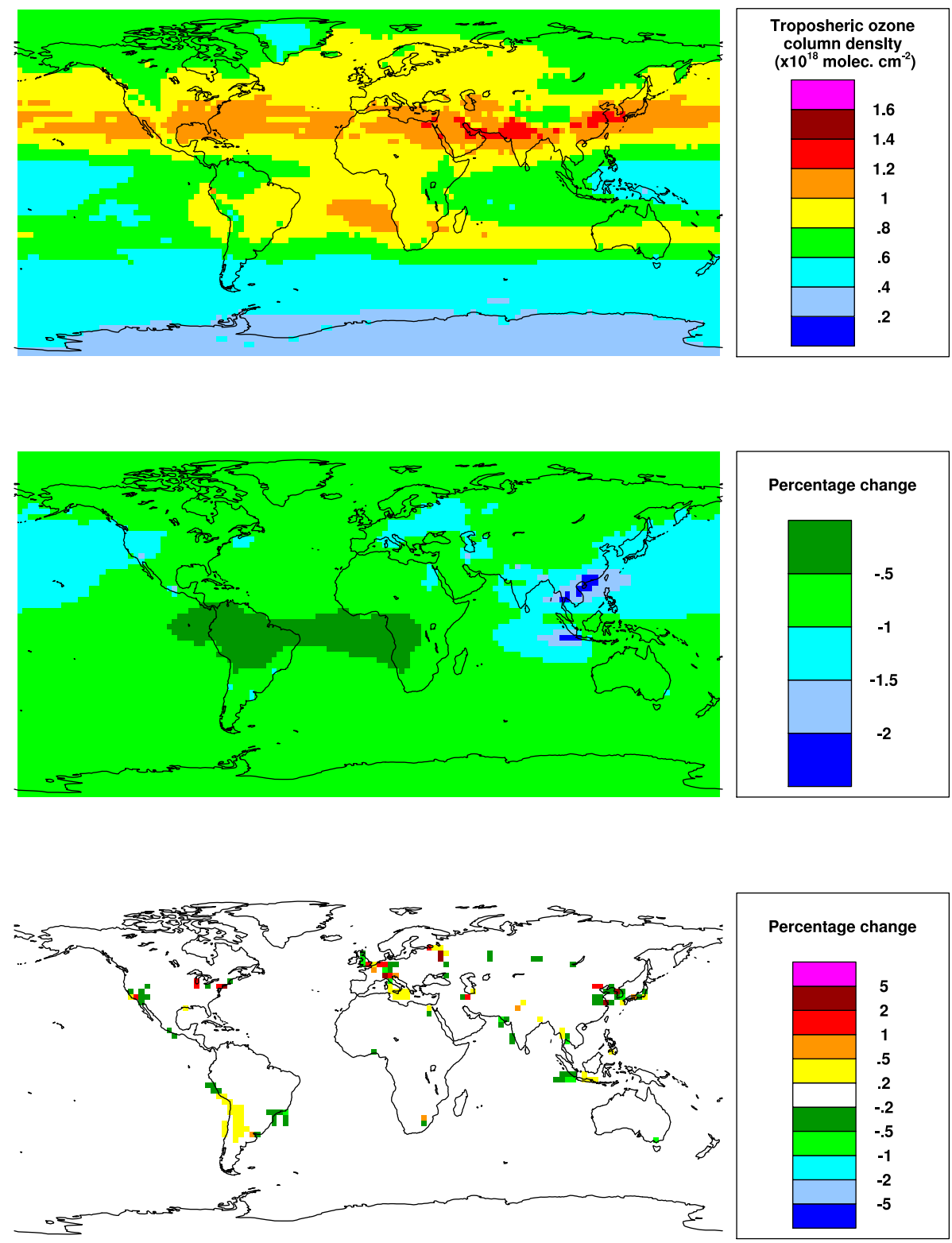

Fig. 5. Top panel: tropospheric ozone column density $\left(\times 10^{18}\right.$ molecules $\left.\mathrm{cm}^{-2}\right)$ from the 2005 base model run $\left(1 \times 10^{18}\right.$ molecules $\mathrm{cm}^{-2}$ is approximately 37 Dobson Units). Middle panel: percentage change in tropospheric ozone column density from the 2005 base model run when emissions from megacities are masked. Bottom panel: percentage change in the surface ozone mixing ratio in the RCP-8.5 simulation for 2005 when $25 \%$ of the megacity emissions are redistributed throughout their host countries.

consistent with the projected changes in ozone precursor emissions under these different scenarios (Fig. 1), and similar to the changes in tropospheric ozone noted by Lamarque et al. (2011) from transient simulations using the same set of four RCP scenarios. The tropospheric background ozone increases throughout the 21 st century in RCP- 8.5 despite slight decreases in emissions of $\mathrm{CO}, \mathrm{NO}_{\mathrm{x}}$ and NMVOC (Fig. 1) due to the increasing mixing ratios of methane under this scenario (Lamarque et al., 2011). The percentage changes in tropospheric ozone from each future base run compared with the 2005 base run are also shown in Fig. S4 of the Supplement to this article. There are regional differences between the different scenarios, but by 2100 all scenarios except RCP-8.5 and RCP-8.5-P show widespread decreases in tropospheric ozone column density. The geographical distribution of changes in the ozone column density, and therefore also of radiative forcing due to ozone are almost identical in RCP-8.5 and RCP-8.5-P, indicating that the choice of downscaling method is not important for global chemistry-climate simulations. 
Table 2. Global, tropospheric average ozone column density $\left(\times 10^{18}\right.$ molecules $\left.\mathrm{cm}^{-2}\right)$ from the base model runs, and the percentage reduction in column density when megacity emissions are removed (in parentheses).

\begin{tabular}{lcccc}
\hline & 2005 & 2030 & 2050 & 2100 \\
\hline RCP-8.5 & $0.75(0.84)$ & $0.80(0.55)$ & $0.82(0.29)$ & $0.87(0.18)$ \\
RCP-8.5-P & - & $0.79(0.72)$ & $0.82(0.52)$ & $0.87(0.38)$ \\
RCP-6.0 & - & $0.74(0.93)$ & $0.74(0.89)$ & $0.66(0.59)$ \\
RCP-4.5 & - & $0.77(0.87)$ & $0.75(0.70)$ & $0.69(0.45)$ \\
RCP-2.6 & - & $0.72(0.92)$ & $0.71(0.84)$ & $0.60(0.62)$ \\
\hline
\end{tabular}

Compared with the expected future changes in tropospheric ozone column density and the differences between the various future scenarios, the effect of masking the emissions from megacities in each of these base runs is very small. The changes in global, tropospheric ozone column densities due to megacity emissions reported in Table 2 are relatively modest (changes of about 0.2 to $0.9 \%$, with a $0.84 \%$ change for the 2005 base run) compared with the percentage of ozone precursors emitted from the megacity grid cells (2-10\%, Fig. 3). Butler and Lawrence (2009) also noted a disproportionately small impact of emissions from megacities on tropospheric ozone.

The change in tropospheric ozone column density in the 2005 base run due to the masking of emissions from megacities (the "annihilation" scenario) is shown in Fig. 5, middle panel. There is a fairly uniform reduction of between $0.5 \%$ and $1 \%$ globally, with regions of greater reduction close to tropical megacities, emissions from which are more likely to be transported vertically by deep convection (Lawrence et al., 2007). Masking generally has a similar effect on each of the future scenario base runs, with the exception of the future scenario runs using RCP-8.5, in which the effect of masking the megacities decreases more quickly than the other scenarios. This is consistent with the declining percentage of emissions due to megacities under this scenario, as seen in global average in Fig. 3, which is due to the changes in the underlying distribution of the sector-based emissions in this scenario caused by the downscaling method (Sect. 2.3). Even when the percentage of terrestrial anthropogenic emissions due to megacities is held constant at 2005 levels by using proportional downscaling in the RCP-8.5-P scenario, the impact of megacity emissions on tropospheric ozone still decreases throughout the 21st century (Table 2). This is consistent with the overall decline in terrestrial anthropogenic emissions under RCP-8.5 relative to non-terrestrial anthropogenic emissions (Fig. 2) as well as the increasingly polluted global background due to increasing amounts of $\mathrm{CH}_{4}$, as noted by Lamarque et al. (2011).

By 2100 , the RCP-2.6 scenario shows a larger global impact of megacity emissions on tropospheric ozone column density than any of the other scenarios studied here (Table 2), due to the cleaner global background and the rel- ative importance of terrestrial anthropogenic sources compared with other scenarios (Fig. 2). The lack of any change in the underlying per-sector emissions distribution under RCP2.6 (Fig. 4) due to the proportional downscaling method used in its construction may mean that megacity emissions, and therefore their global impact, are overestimated in RCP-2.6 (as may be the case in any scenario created using proportional downscaling).

The results from these "annihilation" model runs are consistent with those of Butler and Lawrence (2009), who used essentially the same methodology. In the current study the previous work is extended by employing a redistribution methodology, as explained in Sect. 3. The effect of a $25 \%$ redistribution of emissions from megacity grid cells into the remaining grid cells within each host country on the ozone mixing ratio in the lowest model level is shown for the 2005 base run in Fig. 5, bottom panel. The effect on global tropospheric ozone from the redistribution of megacity emissions is negligible. Total global emissions of ozone precursors are not affected by the redistribution of emissions. The effects of the redistribution are greatest in the lowest model layers in the model grid cells which contain these megacities.

\subsection{Megacity grid cell scale}

The ozone in these megacity grid cells is examined in more detail in Figs. 6, 7 and 8. Previous work (Butler et al., 2008) has shown that individual megacities, which typically occupy about three $0.5 \times 0.5^{\circ}$ emissions grid cells, can be poorly represented in global emissions inventories; compared with detailed city-scale inventories, emissions from individual megacities can be over- or underestimated by a factor of two. For this reason, the analysis presented here does not focus on any individual megacities, but instead examines the collective features of all megacities taken together. Figure 6 shows the seasonal cycle of monthly average ozone mixing ratio from all of the megacities considered in this study in the 2005 base model run (left panel), along with the percentage change in ozone mixing ratio from the 2005 "redistributed" run compared with the 2005 base run (right panel).

Figure 7 shows the percentage change in ozone mixing ratio from all future scenario base runs relative to the 2005 base run. All scenarios show a large relative increase in ozone mixing ratios in megacities higher than $45^{\circ}$ latitude in the winter months. This is consistent with decreasing emissions of NO (Fig. 1) leading to less titration of background ozone during this time, although absolute ozone levels in these grid cells in winter time are not especially high compared with the summer months (Fig. 6). By 2100, summertime ozone has decreased in the megacity grid cells by up to $40 \%$ in all scenarios except both versions of RCP-8.5, where summertime ozone actually increases relative to 2005 in the megacity grid cells. This is despite the strongly decreasing emissions of ozone precursor emissions in these megacity grid cells under the standard version of RCP-8.5 (Sect. 2.3) due to the 


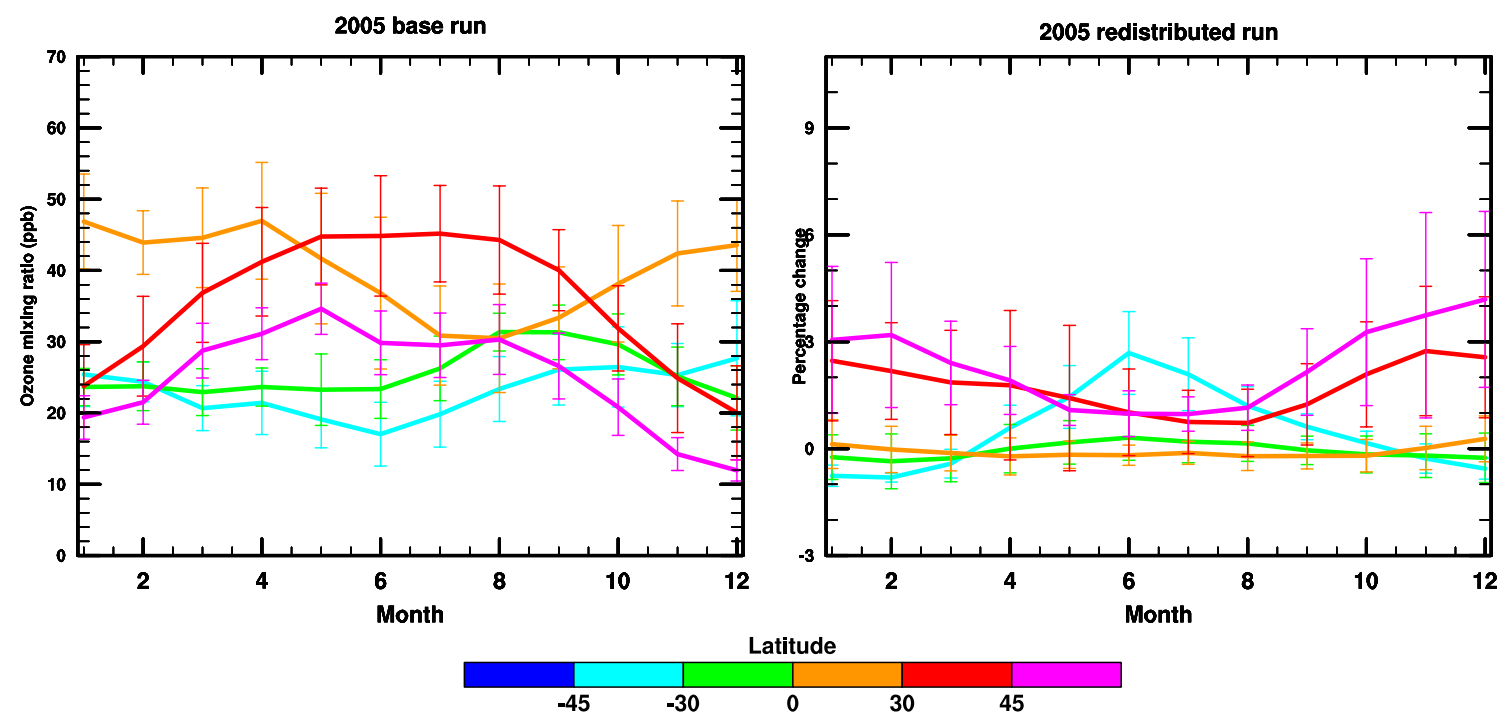

Fig. 6. Left panel: seasonal cycle of monthly mean ozone mixing ratio in model grid cells containing a megacity. Right panel: percentage change in monthly mean megacity ozone mixing ratio when megacity emissions are reduced by $25 \%$ and redistributed throughout the host countries. Means are presented for cities in latitude bands given by the color scale. Bars denote one standard deviation from the mean.

downscaling methodology used. The increased tropospheric background ozone under RCP-8.5 and RCP-8.5-P (Table 2) contributes to increased year-round ozone in the megacity grid cells under these scenarios, whereas the decreased tropospheric background ozone in all other scenarios contributes to decreased summertime ozone in megacities.

\subsection{Megacity sensitivity to local emissions}

The effects of the redistribution of megacity emissions on the ozone mixing ratio in the megacity grid cells are shown as a percentage change (calculated as $\left(\frac{R_{\text {red }}-R_{\text {base }}}{R_{\text {base }}}\right) \times 100$, where $R_{\text {base }}$ and $R_{\text {red }}$ are the ozone mixing ratios in the base and redistributed cases respectively) for 2030, 2050, and 2100 using all future RCP scenarios in Fig. 8. Under all future scenarios, the effect of the $25 \%$ emissions redistribution decreases relative to its size in 2005 (Fig. 8). This indicates that the ozone mixing ratio in these megacity grid cells becomes less sensitive to the local emissions from these grid cells under all future scenarios, and more influenced by ozone produced external to the megacities than under present-day conditions.

Out of all the future scenarios, the RCP- 8.5 scenario shows the lowest influence of local megacity emissions on the local surface ozone mixing ratio. This is due to the changes in the underlying per-sector emissions distributions under RCP-8.5 due to the downscaling methodology employed (Sect. 2.3), in which emissions from megacity grid cells contribute less to the total anthropogenic emissions of ozone precursors than under all other scenarios (Fig. 3). Under the RCP-8.5-P scenario, in which the standard RCP-8.5 scenario was modified to use a proportional downscaling methodology, the influence of megacities on their own air quality is higher than un- der RCP-8.5, due to the greater emissions from megacity grid cells which result from this downscaling method. Compared with 2005, however, megacities in RCP-8.5-P are more influenced by external air quality by 2100 , due to the increase in the background ozone mixing ratio over the 21 st century (Table 2 and Fig. 7). Both effects contribute to the low sensitivity of megacity ozone to changes in local emissions under RCP8.5: the reduction of emissions from the megacity grid cells; and the increase in the polluted tropospheric background.

Under the cleanest scenario, RCP-2.6, the local influence of megacity emissions on ozone air quality remains the highest by the year 2100 compared with all other scenarios. This is consistent with the lower background ozone mixing ratio in this scenario (Table 2), and the increase in the proportion of anthropogenic NO emissions due to megacities under RCP-2.6 (Fig. 3), which is related to the especially large global decline in NO emissions from shipping and aircraft (Fig. 2). The use of the proportional downscaling methodology in RCP-2.6, leading to the lack of any change in the underlying per-sector emissions distribution, probably also contributes to the relatively high influence of megacities on their own air quality in RCP-2.6. The use of an alternative downscaling methodology, in which emissions controls are assumed to be implemented in highly populated areas, could be expected to lower the sensitivity of megacity ozone air quality under RCP-2.6 to local emissions, analogous to the difference between RCP-8.5 and RCP-8.5-P (Fig. 8).

\section{Conclusions}

Megacities have a modest influence on global tropospheric ozone. Under near-present-day conditions, as represented by 

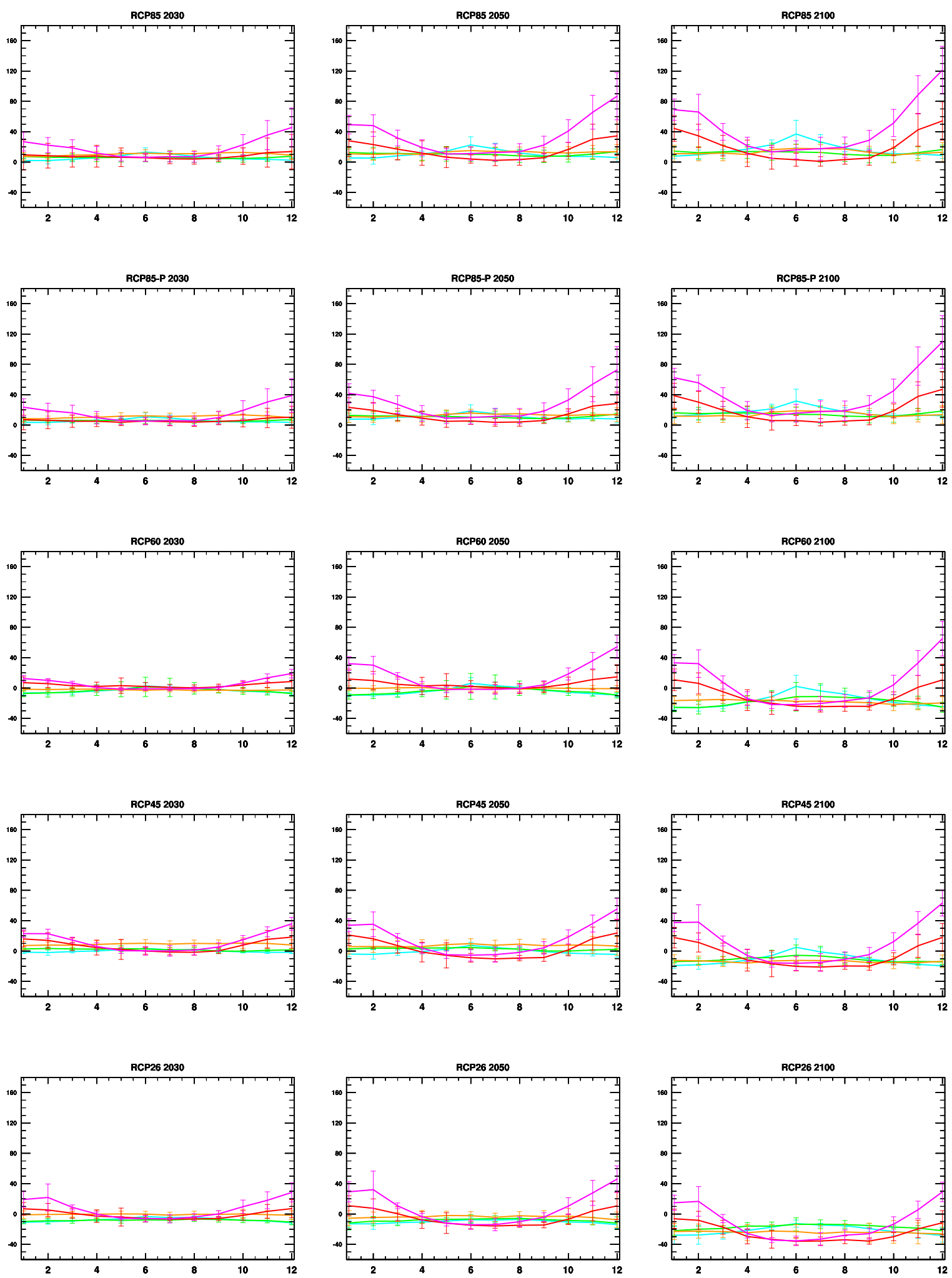

Fig. 7. Percentage difference in the seasonal cycles of monthly average surface ozone mixing ratio in megacity grid cells compared with the 2005 base run. Left to right: years 2030; 2050; and 2100. Top to bottom: RCP-8.5; RCP-8.5-P; RCP-6.0; RCP-4.5; and RCP-2.6. Lines for each latitude band are coloured as in Fig. 6. 

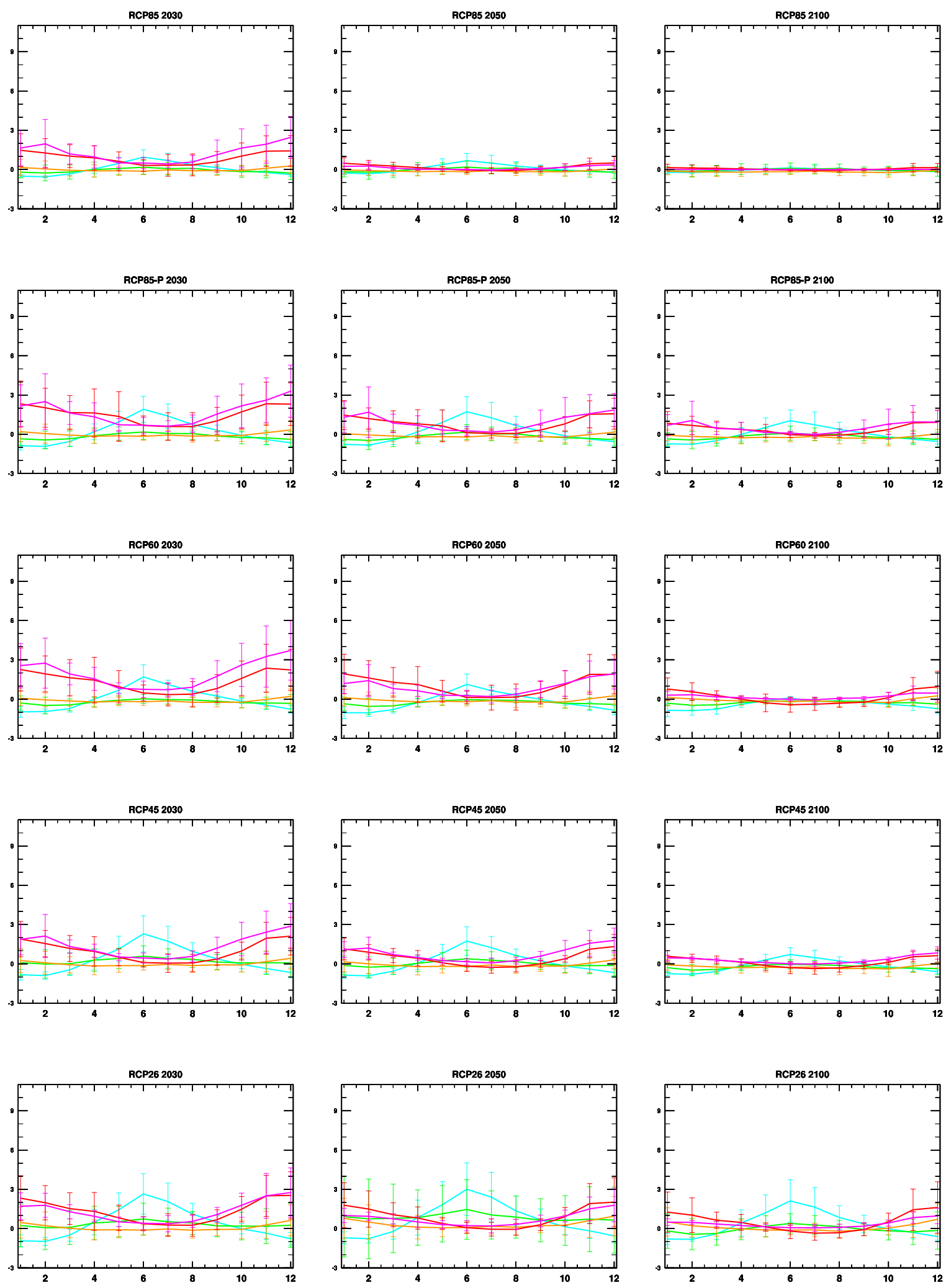

Fig. 8. Percentage change in surface ozone in megacity grid cells when megacity emissions are reduced by $25 \%$ and redistributed throughout the host countries. Left to right: years 2030; 2050; and 2100. Top to bottom: RCP-8.5; RCP-8.5-P; RCP-6.0; RCP-4.5; and RCP-2.6. Lines for each latitude band are coloured as in Fig. 6. 
the year 2005 from the RCP-8.5 "business as usual" emission scenario, emissions from megacities contribute $0.84 \%$ to the global average tropospheric ozone column density, which is proportionally smaller than the $6 \%$ of global anthropogenic ozone precursor emissions (or $4 \%$ of total global anthropogenic and natural NO emissions) due to megacities. Under RCP-8.5 the megacity proportion of total anthropogenic emissions declines still further throughout the 21 st century, due to the spatially explicit downscaling method used to produce the scenario, in which the distribution of population in each country changes dynamically throughout the 21 st century, and the emissions reduction measures modelled as part of the scenario are allocated gridcell-by-gridcell within each country in a way which minimises the exposure of the population to pollutants. This leads to a future shift of land based anthropogenic emissions away from their present day hot spots, especially megacities. Combined with an increase in the global background tropospheric ozone amount, this leads to a decline in the future contribution of megacities to tropospheric ozone under the RCP- 8.5 scenario to $0.18 \%$ by the year 2100 .

In contrast, the "cleaner" RCP-2.6 scenario, while also calculating a fully consistent socioeconomic future scenario including measures to reduce greenhouse gases and ozone precursor emissions, uses a much simpler proportional downscaling method, which assumes that the geographical distribution of population and emissions remains constant throughout the 21 st century. The result of this downscaling is that the megacity proportion of total anthropogenic emissions does not decline into the 21 st century, but in fact increases due to a projected decline in emissions from aircraft and shipping. Combined with cleaner background tropospheric ozone conditions in RCP-2.6, the global impact of megacities reaches $0.92 \%$ in 2030 before falling to $0.63 \%$ in 2100 .

The use of a novel emissions redistribution methodology in this study has allowed the study of the extent to which ozone air quality in megacities is influenced by the local emissions from the megacities themselves, compared to the influence of ozone produced outside of the megacities. Under all future scenarios, the influence of megacities on their local air quality decreases throughout the 21 st century; megacity ozone air quality under all future scenarios becomes more strongly influenced by ozone production external to those cities, especially when the geographical distribution of future emission controls is taken into account. A contribution from externally produced ozone has already been suggested as a significant influence on ozone air quality in the megacities of the developed world, and the analysis presented here shows that this is projected to continue in the developing world under the RCP scenarios, especially RCP-8.5. An assessment of possible effects on tropospheric ozone of changes in biogenic emissions of $\mathrm{NO}_{\mathrm{x}}$ and NMVOC, or changes in atmospheric circulation patterns and corresponding changes in stratosphere-troposphere exchange or production of light- ning $\mathrm{NO}_{\mathrm{x}}$ is beyond the scope of this study. Changes to the tropospheric ozone budget due to these other factors would be expected to influence our results quantitatively but not qualitatively. Nevertheless, results presented here suggest that understanding background tropospheric ozone will become more important throughout the 21 st century.

Despite the broad similarities between the ozone precursor emissions from the RCP scenarios, it has been shown here that differences in the way the scenarios are constructed can influence the results of this analysis. The spatial downscaling method in particular plays an important role. The RCP-8.5 scenario, which explicitly considers the movement of populations within countries and the locations in which emissions controls will be implemented, shows a much higher influence of the regional background ozone on local air quality in megacities than the other scenarios which do not explicitly consider these effects, including a modified version of the RCP-8.5 scenario itself.

This highlights a deficiency in many current emissions projections: the geographical distribution of the emissions. Emissions datasets for use in global modelling studies such as the RCP scenarios are not constructed with such applications in mind as the study of regions as geographically small as megacities, or indeed for the study of air quality at any scale, but rather for long term coupled chemistry-climate simulations. For these applications the details of the spatial distribution of emissions within countries is not important; simulations using future emissions from the spatially-explicit RCP-8.5 scenario redistributed with the present-day emissions pattern produce fields of tropospheric ozone which for the purposes of radiative forcing calculations are essentially the same. There is, however, growing interest in the study of urbanisation, the health effects of the exposure of populations to air pollutants, and the interactions of these processes with climate change. In order to study these effects, sets of emissions scenarios are required which are geographically resolved enough to be useful at small scales, representative of a range of possible emissions control regimes and urbanisation patterns, and consistent with the broader range of projections being used in climate studies.

\section{Supplementary material related to this article is available online at: http://www.atmos-chem-phys.net/12/ 4413/2012/acp-12-4413-2012-supplement.pdf.}

Acknowledgements. The research leading to these results has received funding from the project MEGAPOLI with the European Community's Seventh Framework Programme FP/2007-2011 under grant agreement no 212520. The authors wish to thank Gerd Folberth, Steve Rumbold, Bill Collins, Jos Lelieveld, and JeanFrancois Lamarque for useful discussions during the preparation of this manuscript.

The service charges for this open access publication have been covered by the Max Planck Society. 
Edited by: M. Gauss

\section{References}

Butler, T., Denier van der Gon, H. A. C., and Kuenen, J.: The Base Year (2005) Global Gridded Emission Inventory used in the EU FP7 Project MEGAPOLI (Final Version), MEGAPOLI Scientific Report 11-02, MEGAPOLI-28-REP-2011-01, 2011.

Butler, T. M. and Lawrence, M. G.: The influence of megacities on global atmospheric chemistry: a modelling study, Environ. Chem., 6, 219-225, doi:10.1071/EN08110, 2009.

Butler, T. M., Lawrence, M. G., Gurjar, B. R., van Aardenne, J., Schultz, M., and Lelieveld, J.: The representation of emissions from megacities in global emission inventories, Atmos. Environ., 42, 703-716, 2008.

EPA: Our nation's air: Status and trends through 2008, Tech. Rep. EPA-454/R-09-002, US Environmental Protection Agency, Office of air quality planning and standards, Research Triangle Park, North Carolina, USA, 2010.

Fiore, A. M., Dentener, F. J., Wild, O., Cuvelier, C., Schultz, M. G., Hess, P., Textor, C., Schulz, M., Doherty, R. M., Horowitz, L. W., MacKenzie, I. A., Sanderson, M. G., Shindell, D. T., Stevenson, D. S., Szopa, S., Van Dingenen, R., Zeng, G., Atherton, C., Bergmann, D., Bey, I., Carmichael, G., Collins, W. J., Duncan, B. N., Faluvegi, G., Folberth, G., Gauss, M., Gong, S., Hauglustaine, D., Holloway, T., Isaksen, I. S. A., Jacob, D. J., Jonson, J. E., Kaminski, J. W., Keating, T. J., Lupu, A., Marmer, E., Montanaro, V., Park, R. J., Pitari, G., Pringle, K. J., Pyle, J. A., Schroeder, S., Vivanco, M. G., Wind, P., Wojcik, G., Wu, S., and Zuber, A.: Multimodel estimates of intercontinental sourcereceptor relationships for ozone pollution, J. Geophys. Res., 114, D04301, doi:10.1029/2008JD010816, 2009.

Grimm, N. B., Faeth, S. H., Golubiewski, N. E., Redman, C. L., Wu, J., Bai, X., and Briggs, J. M.: Global change and the ecology of cities, Science, 319, 756-760, doi:10.1126/science.1150195, 2008.

Gurjar, B. R., Butler, T. M., Lawrence, M. G., and Lelieveld, J.: Evaluation of emissions and air quality in megacities, Atmos. Environ., 42, 1593-1606, doi:10.1016/j.atmosenv.2007.10.048, 2008.

Harpercollins Reference: Collins World Atlas, ISBN: 9780007269655, 2008.

Jacob, D., Logan, J., and Murti, P.: Effect of rising Asian emissions on surface ozone in the United States, Geophys. Res. Lett., 26, 2175-2178, doi:10.1029/1999GL900450, 1999.

Kleinman, L. I.: Low and high $\mathrm{NO}_{\mathrm{x}}$ tropospheric photochemistry, J. Geophys. Res., 99, 16831-16838, 1994.

Klippel, T., Fischer, H., Bozem, H., Lawrence, M. G., Butler, T., Jöckel, P., Tost, H., Martinez, M., Harder, H., Regelin, E., Sander, R., Schiller, C. L., Stickler, A., and Lelieveld, J.: Distribution of hydrogen peroxide and formaldehyde over Central Europe during the HOOVER project, Atmos. Chem. Phys., 11, 4391-4410, doi:10.5194/acp-11-4391-2011, 2011.

Lamarque, J.-F., Bond, T. C., Eyring, V., Granier, C., Heil, A., Klimont, Z., Lee, D., Liousse, C., Mieville, A., Owen, B., Schultz, M. G., Shindell, D., Smith, S. J., Stehfest, E., Van Aardenne, J., Cooper, O. R., Kainuma, M., Mahowald, N., McConnell, J. R., Naik, V., Riahi, K., and van Vuuren, D. P.: Historical (1850-2000) gridded anthropogenic and biomass burning emissions of reactive gases and aerosols: methodology and application, Atmos. Chem. Phys., 10, 7017-7039, doi:10.5194/acp10-7017-2010, 2010.

Lamarque, J.-F., Kyle, G., Meinshausen, M., Riahi, K., Smith, S., van Vuuren, D., Conley, A., and Vitt, F.: Global and regional evolution of short-lived radiatively-active gases and aerosols in the Representative Concentration Pathways, Clim. Change, 109, 191-212, doi:10.1007/s10584-011-0155-0, 2011.

Lawrence, M. G., Crutzen, P. J., Rasch, P. J., Eaton, B. E., and Mahowald, N. M.: A model for studies of tropospheric photochemistry: Description, global distributions and evaluation, J. Geophys. Res., 104, 26245-26277, 1999.

Lawrence, M. G., Butler, T. M., Steinkamp, J., Gurjar, B. R., and Lelieveld, J.: Regional pollution potentials of megacities and other major population centers, Atmos. Chem. Phys., 7, 39693987, doi:10.5194/acp-7-3969-2007, 2007.

Masui, T., Matsumoto, K., Hijioka, Y., Kinoshita, T., Nozawa, T., Ishiwatari, S., Kato, E., Shukla, P., Yamagata, Y., and Kainuma, M.: An emission pathway for stabilization at $6 \mathrm{Wm}^{-2}$ radiative forcing, Clim. Change, 109, 59-76, doi:10.1007/s10584-0110150-5, 2011.

Mayer, M., Wang, C., Webster, M., and Prinn, R. G.: Linking local air pollution to global chemistry and climate, J. Geophys. Res., 105, 22869-22896, 2000.

Moss, R. H., Edmonds, J. A., Hibbard, K. A., Manning, M. R., Rose, S. K., van Vuuren, D. P., Carter, T. R., Emori, S., Kainuma, M., Kram, T., Meehl, G. A., Mitchell, J. F. B., Nakicenovic, N., Riahi, K., Smith, S. J., Stouffer, R. J., Thomson, A. M., Weyant, J. P., and Wilbanks, T. J.: The next generation of scenarios for climate change research and assessment, Nature, 463, 747-756, doi:10.1038/nature08823, 2010.

Parrish, D. D., Aikin, K. C., Oltmans, S. J., Johnson, B. J., Ives, M., and Sweeny, C.: Impact of transported background ozone inflow on summertime air quality in a California ozone exceedance area, Atmos. Chem. Phys., 10, 10093-10109, doi:10.5194/acp10-10093-2010, 2010.

Parrish, D. D., Singh, H. B., Molina, L., and Madronich, S.: Air quality progress in North American megacities: A review, Atmos. Environ., 45, 7015-7025, doi:10.1016/j.atmosenv.2011.09.039, 2011.

Prather, M., Gauss, M., Berntsen, T., Isaksen, I., Sundet, J., Bey, I., Brasseur, G., Dentener, F., Derwent, R., Stevenson, D., Grenfell, L., Hauglustaine, D., Horowitz, L., Jacob, D., Mickley, L., Lawrence, M. G., von Kuhlmann, R., Muller, J.-F., Pitari, G., Rogers, H., Johnson, M., Pyle, J., Law, K., van Weele, M., and Wild, O.: Fresh air in the 21 st century?, Geophys. Res. Lett., 30, 1100, doi:10.1029/2002GL016285, 2003.

Riahi, K., Rao, S., Krey, V., Cho, C., Chirkov, V., Fischer, G., Kindermann, G., Nakicenovic, N., and Rafaj, P.: RCP 8.5 - A scenario of comparatively high greenhouse gas emissions, Clim. Change, 109, 33-57, doi:10.1007/s10584-011-0149-y, 2011.

Shindell, D. T., Faluvegi, G., Stevenson, D. S., Krol, M. C., Emmons, L. K., Lamarque, J. F., Pétron, G., Dentener, F. J., Ellingson, K., Shultz, M. G., Wild, O., Amann, M., Atherton, C. S., Bergmann, D. J., Bey, I., Butler, T., Cofala, J., Collins, W. J., Derwent, R. G., Doherty, R. M., Drevet, J., Eskes, H. J., Fiore, A. M., Gauss, M., Hauglustaine, D. A., Horowitz, L. W., Isaksen, I. S. A., Lawrence, M. G., Montanaro, V., Müller, J. F., Pitari, G., Prather, M. J., Pyle, J. A., Rast, S., Rodriguez, J. M., 
Sanderson, M. G., Savage, N. H., Strahan, S. E., Sudo, K., Szopa, S., Unger, N., van Noije, T. P. C., and Zeng, G.: Multi-model simulations of carbon monoxide: Comparison with observations and projected near-future changes, J. Geophys. Res., 111, D19306, doi:10.1029/2006JD007100, 2006.

Sillman, S.: The relation between ozone, $\mathrm{NO}_{\mathrm{x}}$ and hydrocarbons in urban and polluted rural environments, Atmos. Environ., 33, 1821-1845, 1999.

Stevenson, D. S., Dentener, F. J., Schultz, M. G., Ellingsen, K., van Noije, T. P. C., Wild, O., Zeng, G., Amann, M., Atherton, C. S., Bell, N., Bergmann, D. J., Bey, I., Butler, T., Cofala, J., Collins, W. J., Derwent, R. G., Doherty, R. M., Drevet, J., Eskes, H. J., Fiore, A. M., Gauss, M., Hauglustaine, D. A., Horowitz, L. W., Isaksen, I. S. A., Krol, M. C., Lamarque, J. F., Lawrence, M. G., Montanaro, V., Müller, J. F., Pitari, G., Prather, M. J., Pyle, J. A., Rast, S., Rodriguez, J. M., Sanderson, M. G., Savage, N. H., Shindell, D. T., Strahan, S. E., Sudo, K., and Szopa, S.: Multi-model ensemble simulations of present-day and near-future tropospheric ozone, J. Geophys. Res., 111, D08301, doi:10.1029/2005JD006338, 2006.

Thomson, A., Calvin, K., Smith, S., Kyle, G., Volke, A., Patel, P., Delgado-Arias, S., Bond-Lamberty, B., Wise, M., Clarke, L., and Edmonds, J.: RCP4.5: a pathway for stabilization of radiative forcing by 2100, Clim. Change, 109, 77-94, doi:10.1007/s10584-011-0151-4, 2011.

UNEP: Integrated assessment of black carbon and tropospheric ozone: summary for decision makers, Tech. Rep. UNEP/GC/26/INF/20, United Nations Environment Program, 2011.

UNFPA: State of World Population 2007: Unleashing the Potential of Urban Growth, 2007.

van Aardenne, J. A., Dentener, F. J., Olivier, J. G. J., Goldewijk, C. G. M. K., and Lelieveld, J.: A $1^{\circ} \times 1^{\circ}$ resolution data set of historical anthropogenic trace gas emissions for the period 18901990, Global Biogeochem. Cy., 15, 909-928, 2001.

van Noije, T. P. C., Eskes, H. J., Dentener, F. J., Stevenson, D. S., Ellingsen, K., Schultz, M. G., Wild, O., Amann, M., Atherton, C. S., Bergmann, D. J., Bey, I., Boersma, K. F., Butler, T., Cofala, J., Drevet, J., Fiore, A. M., Gauss, M., Hauglustaine, D. A., Horowitz, L. W., Isaksen, I. S. A., Krol, M. C., Lamarque, J.-F., Lawrence, M. G., Martin, R. V., Montanaro, V., Müller, J.F., Pitari, G., Prather, M. J., Pyle, J. A., Richter, A., Rodriguez, J. M., Savage, N. H., Strahan, S. E., Sudo, K., Szopa, S., and van Roozendael, M.: Multi-model ensemble simulations of tropospheric $\mathrm{NO}_{2}$ compared with GOME retrievals for the year 2000, Atmos. Chem. Phys., 6, 2943-2979, doi:10.5194/acp-62943-2006, 2006. van Vuuren, D., Edmonds, J., Kainuma, M., Riahi, K., Thomson, A., Hibbard, K., Hurtt, G., Kram, T., Krey, V., Lamarque, J.F., Masui, T., Meinshausen, M., Nakicenovic, N., Smith, S., and Rose, S.: The representative concentration pathways: an overview, Clim. Change, 109, 5-31, doi:10.1007/s10584-0110148-z, 2011a.

van Vuuren, D., Stehfest, E., den Elzen, M., Kram, T., van Vliet, J., Deetman, S., Isaac, M., Klein Goldewijk, K., Hof, A., Mendoza Beltran, A., Oostenrijk, R., and van Ruijven, B.: RCP2.6: exploring the possibility to keep global mean temperature increase below $2{ }^{\circ} \mathrm{C}$, Clim. Change, 109, 95-116, doi:10.1007/s10584-011-0152-3, 2011b.

van Vuuren, D. P., Smith, S. J., and Riahi, K.: Downscaling socioeconomic and emissions scenarios for global environmental change research: a review, Wiley Interdiscip. Rev.-Clim. Chang., 1, 393-404, doi:10.1002/wcc.50, 2010.

Voigt, C., Schumann, U., Jurkat, T., Schäuble, D., Schlager, H., Petzold, A., Gayet, J.-F., Krämer, M., Schneider, J., Borrmann, S., Schmale, J., Jessberger, P., Hamburger, T., Lichtenstern, M., Scheibe, M., Gourbeyre, C., Meyer, J., Kübbeler, M., Frey, W., Kalesse, H., Butler, T., Lawrence, M. G., Holzäpfel, F., Arnold, F., Wendisch, M., Döpelheuer, A., Gottschaldt, K., Baumann, R., Zöger, M., Sölch, I., Rautenhaus, M., and Dörnbrack, A.: In-situ observations of young contrails - overview and selected results from the CONCERT campaign, Atmos. Chem. Phys., 10, 90399056, doi:10.5194/acp-10-9039-2010, 2010.

von Kuhlmann, R., Lawrence, M. G., and Crutzen, P. J.: A model for studies of tropospheric ozone and nonmethane hydrocarbons: Model evaluation of ozone-related species, J. Geophys. Res., 108, 4729, doi:10.1029/2002JD003348, 2003.

Wild, O. and Prather, M. J.: Global tropospheric ozone modeling: Quantifying errors due to grid resolution, J. Geophys. Res., 111, D11305, doi:10.1029/2005JD006605, 2006.

Yoshitomi, M., Wild, O., and Akimoto, H.: Contributions of regional and intercontinental transport to surface ozone in the Tokyo area, Atmos. Chem. Phys., 11, 7583-7599, doi:10.5194/acp-11-7583-2011, 2011. 